\title{
Paleobiological Perspectives on Early Eukaryotic Evolution
}

\author{
Andrew H. Knoll \\ Department of Organismic and Evolutionary Biology, Harvard University, Cambridge, Massachusetts 02138 \\ Correspondence: aknoll@oeb.harvard.edu
}

Eukaryotic organisms radiated in Proterozoic oceans with oxygenated surface waters, but, commonly, anoxia at depth. Exceptionally preserved fossils of red algae favor crown group emergence more than 1200 million years ago, but older (up to 1600-1800 million years) microfossils could record stem group eukaryotes. Major eukaryotic diversification $\sim 800$ million years ago is documented by the increase in the taxonomic richness of complex, organic-walled microfossils, including simple coenocytic and multicellular forms, as well as widespread tests comparable to those of extant testate amoebae and simple foraminiferans and diverse scales comparable to organic and siliceous scales formed today by protists in several clades. Mid-Neoproterozoic establishment or expansion of eukaryophagy provides a possible mechanism for accelerating eukaryotic diversification long after the origin of the domain. Protists continued to diversify along with animals in the more pervasively oxygenated oceans of the Phanerozoic Eon.

Eukaryotic organisms have a long evolutionEary history, recorded, in part, by conventional and molecular fossils. For the Phanerozoic Eon (the past 542 million years), eukaryotic evolution is richly documented by the skeletons (and, occasionally, nonskeletal remains) of animals, as well as the leaves, stems, roots, and reproductive organs of land plants. Phylogenetic logic, however, tells us that eukaryotes must have a deeper history, one that began long before the first plant and animal fossils formed. To what extent does the geological record preserve aspects of deep eukaryotic history, and can the chemistry of ancient sedimentary rocks elucidate the environmental conditions under which the eukaryotic cell took shape?

\section{EXPECTATIONS FROM COMPARATIVE BIOLOGY}

The diversity of eukaryotic organisms observable today makes two sets of predictions for the fossil record, one phylogenetic and the other preservational. Phylogenies suggest the relative timing of diversification events through Earth history, and, when incorporated into molecular clocks, provide quantitative estimates of divergence times. In turn, experimental and observational studies of postmortem decay indicate that only a subset of eukaryotic clades is likely to be represented in the geologic record and these only under selected environmental circumstances. Together, insights into phylogeny and

Editors: Patrick J. Keeling and Eugene V. Koonin

Additional Perspectives on The Origin and Evolution of Eukaryotes available at www.cshperspectives.org

Copyright (C) 2014 Cold Spring Harbor Laboratory Press; all rights reserved; doi: 10.1101/cshperspect.a016121

Cite this article as Cold Spring Harb Perspect Biol 2014;6:a016121 
A.H. Knoll

preservation provide an empirical guide to paleobiological exploration.

Molecular sequence comparisons have revolutionized our understanding of evolutionary relationships among eukaryotes, but consensus on eukaryotic phylogeny remains elusive. Most researchers recognize a limited number of major clades, including the opisthonkonts, amoebozoans, excavates, plants (sensu lato), and an SAR clade containing the stramenopiles, alveolates, and rhizarians (e.g., Katz 2012), and many recognize the potential for as-yet poorly characterized taxa to expand that roster (e.g., Patterson 1999; Adl et al. 2012). Persistent uncertainties include the position of the root; placement of groups such as centrohelid heliozoans, haptophytes, and cryptomonads; and both the monophyly and relationships of photosynthetic lineages commonly grouped as Plantae.

Molecular clocks calibrated by phylogenetically well-constrained fossils have been used to estimate the timing of early eukaryotic diversification. Choice of algorithm can strongly influence these estimates (Roger and Hug 2006; Eme et al. 2014), but sensitivity tests suggest that for a given set of sampled taxa, at least some estimates are broadly robust to tree topology and calibration choices (e.g., Parfrey et al. 2011). Molecular clock estimates generally agree that much protistan diversification has taken place during the Phanerozoic Eon, paralleling the diversification of animals, plants, and fungi. They also agree on an earlier, Neoproterozoic radiation within the major eukaryotic clades, beginning perhaps 800 million years ago (Mya). Where clocks disagree is on the date for the last common ancestor of extant eukaryotes, with some positing a long interval of eukaryotic evolution before Neoproterozoic radiation (e.g., Hedges et al. 2004; Yoon et al. 2004; Parfrey et al 2011) and others suggesting a shorter fuse (e.g., Douzery et al. 2004; Berney and Pawlowski 2006; Chernikova et al. 2011; Shih and Matzke 2013). The differing predictions of these clock estimates can be tested against the Proterozoic fossil record.

How do protists impart a paleobiological signature to sedimentary rocks? Mineralized protistan skeletons can form significant sedi- mentary accumulations-the White Cliffs of Dover, for example, consist mostly of small calcitic scales made by coccolithophorid algae. Tests and scales of calcite and silica document Phanerozoic evolutionary histories for diatoms, chrysophytes, coccolithophoids, foraminiferans, and radiolarians, but do not extend into Proterozoic rocks (Knoll and Kotrc 2014). Organic cell walls, tests, and scales can also survive bacterial decay, depending on molecular composition, and, in Phanerozoic rocks, these remains record clades that include dinoflagellates and prasinophyte green algae, among other groups. As we shall see, decay-resistant organic walls, tests, and scales also document aspects of Proterozoic protistan evolution, although it can be challenging to relate preserved fossils to extant clades.

Preservation, of course, is not the only hurdle in paleobiological investigations of Proterozoic rocks. There is also the challenge of recognition. In the first instance, how do we identify a fossil as eukaryotic rather than bacterial? Given that the record is one of morphology and not DNA or cytology, diagnostic characters must be sought in the size, shape, ultrastructure, and preservational circumstances of microfossil populations. Eukaryotic cells are commonly larger than bacteria and archaeons, but are not invariably so. Conversely, cyanobacteria commonly form extracellular sheaths and envelopes that may encompass many cells; this being the case, burial can preserve a $100-\mu \mathrm{m}$ cyanobacterial envelope that, in life, surrounded numerous micron-scale cells. By itself, then, size is commonly an insufficient criterion for eukaryotic attribution. Cyst walls associated with resting stages in eukaryotic life cycles commonly have spines or other ornamentation, and they commonly have a complex ultrastructure as observed via TEM (e.g., Javaux et al. 2004). Bacteria can have large envelopes (and more rarely cell size) (Schultz and Jørgensen 2001), but they rarely if ever combine large size, ornamented walls, complex ultrastructure, and a preservable composition; thus, fossils that display all of these characteristics are widely regarded as eukaryotic.

Molecular fossils provide another means by which eukaryotic organisms can impart a sig- 
nature to the geological record. Proteins and nucleic acids have a low probability of preservation, but lipids can preserve well, and sterols in particular have been used to investigate the deep history of eukaryotes. Abundant steranes (the geologically stable derivatives of sterols) extracted from petroleum document a Phanerozoic history of primary producers in the oceans that, to a first approximation, parallels the histories inferred from microfossils and molecular clocks (Knoll et al. 2007). Molecular fossils extend that record into Proterozoic and, more controversially, late Archean rocks.

Together then, phylogenies and preservation potential furnish guides to the paleobiology of early eukaryotic evolution, providing hypotheses of evolutionary history. How well do fossils fit these predictions?

\section{ARCHEAN EUKARYOTES?}

The three-domain view of life, predicated on comparisons of SSU rRNA gene sequences, posited that eukaryotes are sister to the Archaea (Woese et al. 1990). Given this relationship and isotopic evidence for methanogenesis and methanotrophy in the late Archean carbon cycle (Hayes 1994), logic would dictate that the Eukarya existed no later than $\sim 2700$ Mya. This logic, however, is challenged by alternative phylogenies that nest eukaryotes within the Archaea (Williams et al. 2012) and by models for eukaryogenesis that rely on archaeal-bacterial symbiosis (Martin and Müller 1998; Moreira and Lopez Garcia 1998). Even the most generous molecular clock estimates place the last common ancestor of extant eukaryotes within the Proterozoic Eon (Hedges et al. 2004), requiring that any Archean eukaryotes be stem groups.

Unfortunately, the record of life in Archean rocks is sparse and subject to conflicting interpretations. Early diagenetic cherts, a rich source of microfossils in Proterozoic strata, are largely barren, perhaps reflecting the strong influence of hydrothermal fluid flow and iron deposition on the silica cycle of Archean oceans (Fischer and Knoll 2009; Chakrabarti et al. 2012). Shales, in turn, contain abundant organic carbon, but few structurally preserved or morphologically distinctive microfossils. One of the few welldocumented and widely accepted fossil occurrences in earlier Archean rocks, and perhaps the only one that potentially bears on stem group eukaryotes, comes from 3200-Mya shales that contain large $(30-300 \mu \mathrm{m})$ spheroidal vesicles (Javaux et al. 2010). These appear to be genuine fossils, and they could, in principle, be eukaryotic; however, their simple ultrastructure and ready comparison to the extracellular envelopes of some bacteria saps confidence from such an interpretation.

In the absence of a convincing microfossil record, geobiologists have turned to molecular fossils. Steranes of hypothesized eukaryotic origin have been reported from late Archean sedimentary rocks (Brocks et al. 1999; Waldbauer et al. 2009), potentially documenting early eukaryotes, but raising incompletely resolved environmental, phylogenetic, and geological issues. The environmental concern is that sterol biosynthesis requires molecular oxygen, yet geochemical data consistently indicate that the Archean atmosphere and oceans were anoxic (Holland 2006). Sterol synthesis is possible at nanomolar oxygen tensions (Waldbauer et al. 2011), and thus a plausible but unproven solution holds that early cyanobacteria could have generated local oxygen oases within mats or sediments long before $\mathrm{O}_{2}$ began to accumulate in the atmosphere (e.g., Anbar et al. 2007).

The second issue is phylogenetic. A limited number of bacteria synthesize sterols (e.g., Pearson et al. 2005), raising the concern that preserved biomarkers could be of prokaryotic origin. In general, however, bacterial sterol synthesis is limited to simple products such as lanosterol, and thus it is fair to consider more complex steranes of the type found in late Archean rocks as eukaryotic until and unless complex sterol synthesis is shown in free-living bacteria. The third concern, however, is not so easily dismissed. Because steranes in late Archean rocks occur in part-per-billion concentrations, geological or modern contamination must be considered. Fluids flow through sedimentary rocks throughout their history, and biomarkers can also be emplaced during the processes of drill- 
A.H. Knoll

ing and sample processing. Arguments in favor of an indigenous origin for Archean steranes stress the care taken in sample preparation and the varying biomarker composition of different beds, consistent with the expectation of ecological heterogeneity at the time of deposition (Brocks et al. 2003; Waldbauer et al. 2009). Further support comes from steranes and other biomarkers in fluid inclusions from quartz particles in 2400-Mya sedimentary rocks (Dutkiewicz et al. 2006). Critics counter that biomarker heterogeneity could reflect bed-by-bed variations in porosity and permeability, channeling later flow fluid, and note that steranes occur mostly near the surface of drill samples (Brocks 2011) and have a carbon isotopic composition distinct from the bulk of the organic matter in the samples (Rasmussen et al 2008). The debate continues, commendably fueled by new sampling programs marked by stringent protocols for drilling and sample preparation.

\section{PROTEROZOIC ESTABLISHMENT}

As noted above, molecular clocks suggest that regardless of any deeper stem group history, crown group eukaryotes emerged during the Proterozoic Eon. (In this discussion, the term "crown group" is used in its broadly accepted phylogenetic sense to indicate the last common ancestor of all extant members of a clade and its descendants. Earlier, informal usage to denote a diverse subset of eukaryotes has been abandoned.) The last common ancestor of extant eukaryotes possessed a mitochondrion capable of aerobic respiration, consistent with geochemical evidence for the permanent oxygenation of Earth's atmosphere and surface ocean $\sim 2400$ Mya (Holland 2006). Quantification of Proterozoic oxygen levels is difficult, but the persistence of anoxic water masses beneath the surface mixed layer of the oceans suggests that $\mathrm{pO}_{2}$ remained low, perhaps no more than a few percent of present-day atmospheric levels (e.g., Brocks et al. 2005; Canfield 2005; Scott et al. 2008; Johnston et al. 2010; Frei et al. 2013). The chronic challenge of anoxic waters mixed upward from the oxygen minimum zone is consistent with the widespread occurrence in mito- chondria of genes for anaerobic metabolism (Müller et al. 2012).

Bangiomorpha pubsecens (Fig. 2E) (Butterfield 2000) plays a key role in evaluating crown group early and late hypotheses based on molecular clocks. An exceptionally well-preserved population of filamentous microfossils found in silicified peritidal carbonates from Arctic Canada, Bangiomorpha displays several morphological features that collectively place it within the red algae. These include overall morphology, details of thallus development and reproductive biology, cellularly differentiated holdfasts, life cycle characteristics, and details of preservation that differ markedly from those characteristics of silicified cyanobacteria. Many specimens are preserved in life position, rising vertically from attachment sites on the ancient seafloor (Butterfield 2000). Thus, Bangiomorpha is reasonably interpreted as a rhodophyte, although it may branch earlier within the clade than extant Bangiales. Multiple geochronological and stratigraphic constraints indicate that Bangiomorpha lived 1100-1200 Mya (summarized in Knoll et al. 2013). Neither its age nor its phylogenetic attribution is likely to change markedly with continued study, and thus Bangiomorpha favors molecular clocks that place both the last common ancestor of extant eukaryotes and the acquisition of plastids before $~ 1200$ Mya.

Some paleontologists propose that crown group eukaryotes can be traced further back in time. For example, Moczydłowska et al. (2011) have argued that microfossils of green algae occur in rocks as old as 1800 Mya. Accepting that green algae (and land plants) are sister to the red algae, greens must have lived contemporaneously with 1100- to 1200-Mya Bangiomorpha, and molecular clock estimates not precluded by Bangiomorpha's age suggest that the green-red split occurred up to several hundred million years before this (Wang et al. 1999; Yoon et al. 2004; Parfrey et al. 2011). (If, as sometimes proposed, red algae are sister to greens plus glaucocystophytes, the green clade could have radiated later.) The older fossils in question, however, are simple spheroids whose affinities are not easily ascertained (Fig. 1A,B). Moczydłowska et al. (2011) maintain that only algae make resistant 

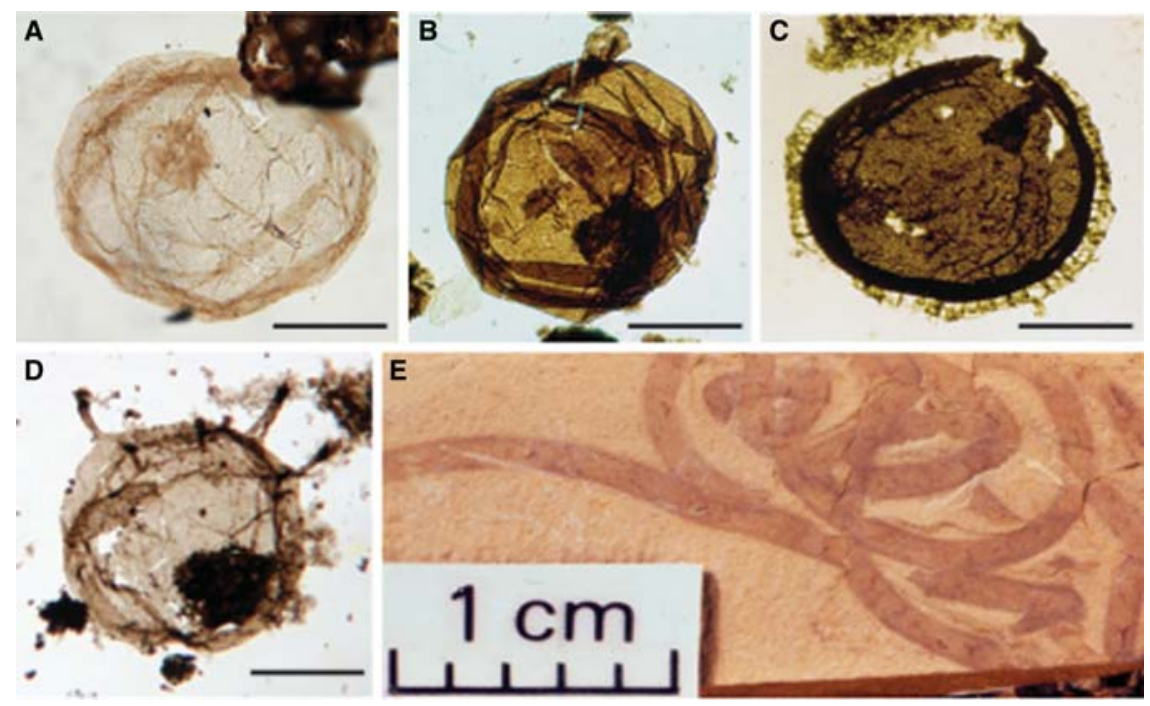

Figure 1. Late Paleo- and Mesoproterozoic fossils interpreted as eukaryotic. $(A-D)$ Preserved spheroidal microfossils interpreted as the vegetative or resting walls of unicellular protists, arranged from lowest confidence $(A)$ to highest $(C$ and $D)$. (A) Unornamented spheroidal vesicle, 1400-1500 Mya Roper Group, Australia. $(B)$ Spheroidal vesicle with corduroy-like ornamentation of vesicle wall, Roper Group. (C) Spheroidal microfossil with surface divided into small fields and ornamented with cylindrical processes that expand distally; TEM of walls shows complex multilayered wall ultrastructure, $>1600$ Mya Ruyang Group, China. (D) Spheroidal vesicle with asymmetrically placed cylindrical processes; TEM shows complex wall ultrastructure, Roper Group (courtesy of Javaux et al. 2004). (E) Macroscopic compressions assigned to the form taxon Grypania, 1400 Mya Jixian Group, China (courtesy of M.R. Walter). Scale bars, $20 \mu \mathrm{m}(A) ; 75 \mu \mathrm{m}(B, D) ; 120 \mu \mathrm{m}(C)$. Note 1-cm scale bar in $E$.

cysts with ornamentation and well-defined excystment structures, but resting cysts have been well described in various heterotrophic protists, including, for example, ciliates that fashion large, spheroidal, and sometimes ornamented cysts with pylome-like excystment structures (e.g., Beers 1948, 1966; Foissner et al. 2007; Verni and Rosati 2011). Wall ultrastructure might provide more definitive evidence of green algae, especially should TEM reveal the distinctive trilaminar wall structure (TLS) characteristic of cell walls in some chlorophytes (Allard and Templier 2000). TLS has been shown in Cambrian green algae (Talyzina and Moczydłowska 2000), but not in the older microfossils under consideration here (Javaux et al. 2004). Biomarker molecules might also provide insight, but steranes are rare in mid-Proterozoic rocks (Brocks et al. 2005; Pawlowska et al. 2013) (see below), and growing evidence suggests that algaenan, an aliphatic polymer known to be synthesized by a limited diversity of green algae (Kodner et al. 2009), can also form during diagenesis (Gupta et al. 2009)—molecular clocks suggest that TLS and algaenan-synthesizing green algae doubtfully extend much below the Proterozoic-Cambrian boundary. Thus, it remains uncertain whether earlier Proterozoic microfossils record crown group green algae, stem group greens (or Plantae), another crown group clade, or stem group eukaryotes (Knoll et al. 2006).

In general, mid-Proterozoic sedimentary rocks contain abundant, but only modestly diverse fossils of probable eukaryotic origin (Javaux 2011). Shales up to $\sim 1600$ Mya contain microfossils that combine large size $(>100 \mu \mathrm{m})$ with complex ultrastructure, structurally complex ornamented or tessellated cell walls, and surface processes of varying form (Fig. 1C,D) (Javaux et al. 2001, 2003, 2004; Xiao et al. 1997; Yin and Yuan 2007; Nagovitsin et al. 2010). Equally large vesicles with less distinctive surface 
A.H. Knoll

morphology or ultrastructure occur in rocks as old as 1800 Mya (Fig. 1A) (Yan 1995; Lamb et al. 2009). These may well be eukaryotic, especially those with corduroy-like, raised parallel ridges on wall surfaces (Fig. 1B) (Yan 1995). For most, however, a lack of diagnostic features underscores residual uncertainty at the domain level. Macroscopic impressions and compressions whose regular morphology suggests a eukaryotic origin also occur in rocks of mid-Proterozoic age (Fig. 1E) (Grey and Williams 1990; Walter et al. 1990; Retallack et al. 2013), with the oldest overlapping in age with possible eukaryotic microfossils (Hofmann and Chen 1981; Han and Runnegar 1992). Most of this record comes from marine rocks, but a possible glimpse of life in Proterozoic lakes has been reported from 1000to 900 -Mya purportedly nonmarine beds in Scotland that preserve a moderate diversity of microfossils likely sourced by protists but otherwise of problematic origin (Strother et al. 2010).

From the preceding paragraphs we can draw two conclusions. First, although one might hope for a clean paleobiological boundary between worlds with and without eukaryotic cells, the geological record actually presents a sliding scale of certainty, from confidently interpreted protists in 1400 - to 1600 -Mya rocks to more ambiguously interpreted remains at $1800 \mathrm{Mya}$ and even more debated morphological and molecular signatures in older successions. Paleobiological evidence of eukaryotic cells does not so much bottom out as fade away. The second conclusion is that the early eukaryotic record could be dominated by stem group taxa. Stem groups are a logical necessity in biology but an empirical challenge for paleontologists. The fossil records of plants and animals contain diverse stem group taxa at varying hierarchical levels, but their characters cannot always be inferred from comparative biology alone-what biologist would have predicted that stem group birds include quadrupeds up to $30 \mathrm{~m}$ long? At present, the inference that early protistan fossils might record stem group eukaryotes (or unrecognized stem groups of major eukaryotic clades) owes more to the absence of diagnostic characters than it does to readily interpreted character combinations.

\section{NEOPROTEROZOIC RADIATION}

Fossil diversity increased only moderately over the first half of recorded eukaryotic history. Then, $\sim 800$ Mya, things changed in the oceans: Both molecular clocks and fossils indicate pronounced diversification within major eukaryotic clades at this time. Organic-walled fossils preserved as compressions in shallow marine mudstones show unprecedented taxonomic richness, including both resting cysts and vegetative cells with complex morphologies, as well as an increased diversity of coenocytic and simple multicellular populations (Fig. 2A-C) (Butterfield et al. 1994; Butterfield 2004, 2005a,b). In early interpretations, many of these fossils were assigned to specific eukaryotic clades, including xanthophytes, green algae, and fungi. Molecular clocks suggest that some of these attributions reflect convergence, but morphology, molecular clock estimates, and preservational potential all support the interpretation of distinctive coenocytic fossils in 750- to 800-Mya rocks as Cladophoralean green algae (Fig. 2C) (Butterfield et al. 1994; Graham et al. 2013). The number of well-preserved fossil assemblages in rocks of this age remains small, and it is possible that continuing exploration will pull the record of accelerating diversification deeper into the past. At present, however, exceptionally preserved microfossil assemblages in older rocks do not record the diversity documented in their 750 - to 800-Mya counterparts (Knoll et al. 2006). Nor is the increase in eukaryotic diversity matched by a jump in observed cyanobacterial diversity, again suggesting that the observed record is not simply an artifact of sampling.

Two classes of eukaryotic fossils are completely unrecorded before $\sim 800$ Mya. Vaseshaped microfossils comparable to tests made by testate amoebans and some simple foraminiferans occur abundantly in mid-Neoproterozoic rocks around the world (Fig. 2D) (Porter and Knoll 2000). Their distinctive mode of preservation, most commonly as casts and molds conspicuous in petrographic thin sections of shale, carbonate, and chert, lowers the probability that these fossils have a deeper history yet to be discovered. More than a dozen taxa have 

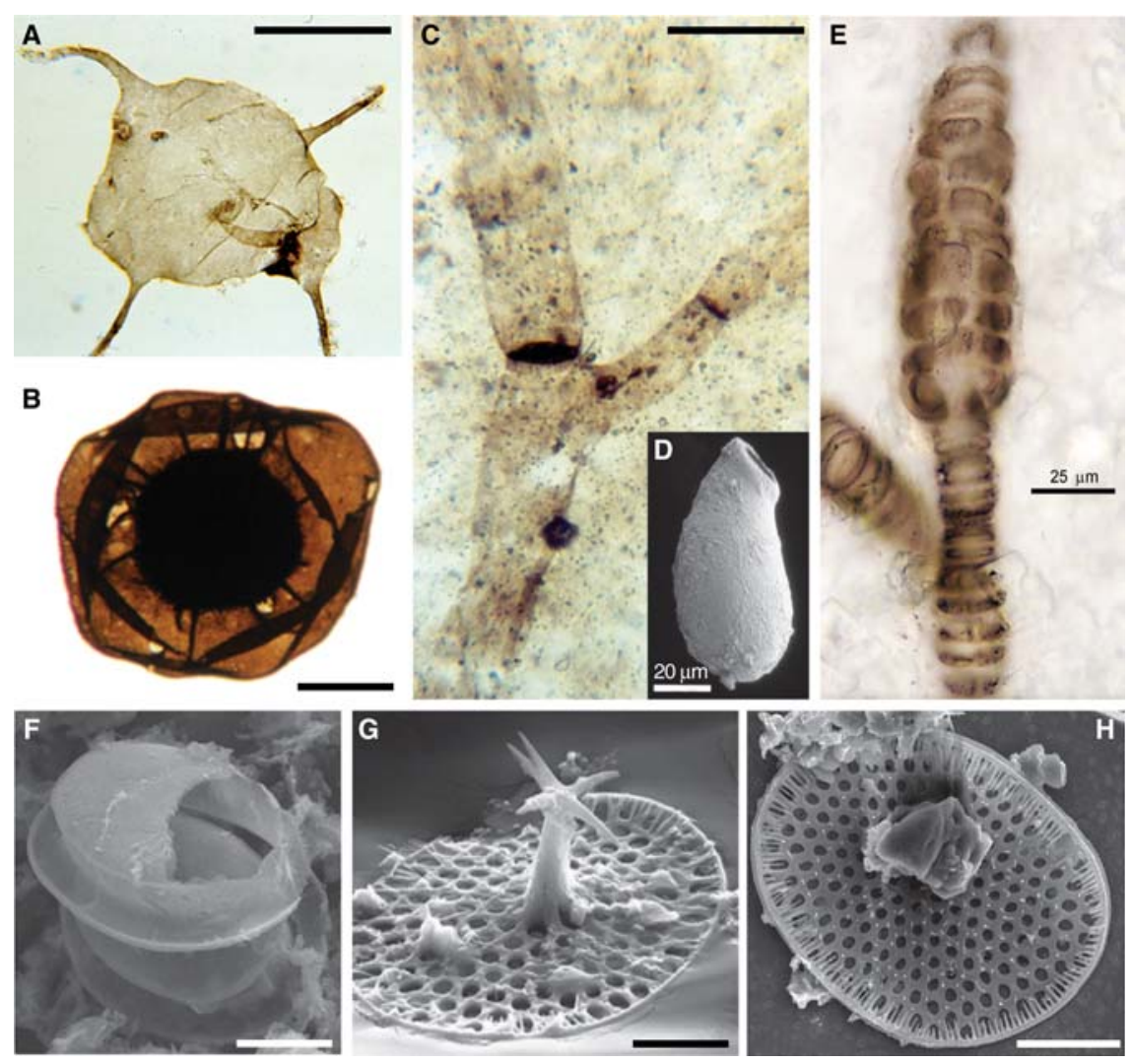

Figure 2. Late Mesoproterozoic and Neoproterozoic fossils interpreted as eukaryotic. (A) Irregularly spheroidal microfossil with long cylindrical processes, 750-800 Mya Svanbergfjellet Formation, Spitsbergen. (B) Large microfossil with opaque inner wall bearing small spines and longer cylindrical processes, within encompassing smoothly spheroidal vesicle, Svanbergfjellet Formation. (C) Cladophora-like branching filamentous microfossil with apparently coenocytic subunits, Svanbergfjellet Formation. (D) Three-dimensionally (3D) preserved mineral replicate of testate eukaryote, Chuar Group, Grand Canyon (courtesy of Porter et al. 2003). (E) Bangiomorpha, interpreted as an early-branching red alga, 1100-1200 Mya Hunting Formation, Arctic Canada (courtesy of Butterfield 2000). (F-H). Scale microfossils preserved three-dimensionally in $\sim 800$-Mya carbonate rocks of the Fifteenmile Group, Yukon Territory, Canada (courtesy of Cohen and Knoll 2013). Scale bars, $60 \mu \mathrm{m}(A, C) ; 120 \mu \mathrm{m}(B) ; 10 \mu \mathrm{m}(F) ; 14 \mu \mathrm{m}(G, H)$. Note scale bars in $D$ and $E$.

been distinguished, and at least some bear close comparison to the tests made today by arcellid amoebozoans (Porter et al. 2003). Others have been compared with euglyphid rhizarians, but young molecular clock estimates for euglyphid diversification suggest, once again, that observed similarities may reflect convergence (Berney and Pawlowski 2006).

The other novel class of microfossils is 10- to $30-\mu \mathrm{m}$ scales preserved in $\sim 800$-Mya rocks from northwestern Canada (Fig. 2F-H). Originally reported by Allison and Hilgert (1986), the fossils were observed in thin sections of chert nodules and interpreted as siliceous scales broadly comparable to those of extant chrysophytes. The discovery, however, that the scales are preserved by mineral phosphate (Cohen et al. 2011) prompted a restudy in which thousands of specimens were recovered by the dissolution of encompassing limestones in weak acid. Some 38 distinctive scale types have been documented in exceptional morphological detail (Cohen and Knoll 2012), making these the most diverse eukaryotic fossils known before 
A.H. Knoll

the Ediacaran diversification of animals. The fossils are assuredly eukaryotic and bear functional comparison to organic or siliceous scales synthesized by diverse protists today. Phylogenetically, however, it is challenging to place any of these taxa within specific eukaryotic clades. Uncertainty remains, as well, as to the original composition of the scales. Does the observed phosphate record biomineralization (Cohen et al. 2011) (interesting if correct, because phosphatic biomineralization is extremely rare among living protists) or early diagenetic phosphate replication within sediments (Cohen and Knoll 2012)? In either event, the scale assemblage from northwestern Canada is, for now, unique.

Fossils, then, record an apparent burst of Neoproterozoic diversification. This paleontological expansion is mirrored by molecular clock estimates, but not, intriguingly, by molecular biomarkers in Neoproterozoic rocks (Pawlowska et al. 2013). Should we interpret the dearth of steranes in pre-Ediacaran sedimentary rocks as evidence of absence or an absence of evidence? Given the close stratigraphic correspondence between the microfossil and biomarker records of Phanerozoic primary producers (Schwark and Empt 2006; Knoll et al. 2007), the lack of eukaryotic biomarkers in older strata has commonly been taken to indicate bacterial (especially cyanobacterial) dominance of primary production. Pawlowska et al. (2013), however, argue that this pattern owes more to preservation than production.

In the view of Pawlowska et al. (2013), microbial mats that covered Proterozoic seafloors were the primary sources of sedimentary organic matter preserved in Proterozoic shales. Moreover, they note that the aggressively oxidizing environments generated diurnally by cyanobacterial oxygen production within mats (e.g., Gingras et al. 2011) would have destroyed lipids sourced from the overlying water column. In consequence, the lack of steranes in most Proterozoic shales may simply reflect preservational circumstances common before the Ediacaran Period, when evolving animals dramatically restricted the distribution of benthic mat communities.
Without question, mats were major contributors of organic matter to Proterozoic sediments, and regardless of other influences, abundant cyanobacteria and other bacteria would have diluted molecular signatures of eukaryotes living in mats or the water column. That said, many of the organic-rich shales sampled for biomarker analysis come from relatively deep basins in which bottom waters were anoxic, mooting the destructive impact of oxygen-rich mat interiors. Petrological examination of Proterozoic shales also suggests the need for a more nuanced view of Proterozoic sediment accumulation. In many Proterozoic shales, mat horizons are separated by variably thick event beds that record pulses of mud deposition. These mud layers are rich in organic matter, providing an avenue for phytoplankton to evade the matseal effect of Pawlowska et al. (2013). Sedimentological observations also suggest that the aerial extent of benthic mats began to decline well before the Ediacaran Period; the case is best made for carbonates, where microbial lamination is much less common in later Neoproterozoic beds than it is in older successions (Knoll and Swett 1990).

Phanerozoic examples show that bacterial primary production was transiently high during episodes of widespread subsurface anoxia in the world's oceans-for example, at the beginning of the Triassic Period (Grice et al. 2005). Thus, we might expect that in Proterozoic oceans with persistent subsurface anoxia, cyanobacteria and other photosynthetic bacteria would dominate primary production (Johnston et al. 2009), in part because of low fixed-nitrogen abundances in surface waters (Fennel et al. 2005). Indeed, Boyle et al. (2013) have argued that, in Proterozoic oceans, sulfidic subsurface water masses could only develop beneath surface waters dominated by nitrogen-fixing primary producers. Conversely, biogeochemical study of Silurian microbial mats shows a strong presence of eukaryotic biomarkers (Bauersachs et al. 2009), suggesting that mat-seals provide imperfect barriers to the burial of eukaryotic lipids.

Thus, although Pawlowska et al.'s (2013) hypothesis usefully urges caution in the interpre- 
tation of Proterozoic steranes (or their absence), its applicability to the broad Proterozoic record remains uncertain. To date, few analyses have targeted 850- to 650-Mya black shales in which molecular biomarkers might be expected to mirror evident microfossil diversification. By the Ediacaran Period, however, steranes are relatively abundant in carbonaceous shales (Knoll et al. 2007). In fact, microfossils suggest a diversification of green algal phytoplankton at about the time when C29 sterols (principally sourced by green algae) (Kodner et al. 2008) became abundant constituents of sedimentary organic matter. Some $20 \%$ of the microfossil taxa in Early Cambrian rocks are confidently interpreted as the phycomata of prasinophyte greens, and additional chlorophyte diversity may be recorded by other preserved cysts (e.g., Moczydłowska 2010).

What might have driven the observed Neoproterozoic diversification of marine eukaryotes? Perhaps we can take a lesson from Cambrian animal radiation. Molecular clocks suggest that animals began to diverge $\sim 800$ Mya; fossils, in turn, indicate the presence of metazoans $40-$ 100 million years before the Cambrian explosion (Erwin et al. 2011). Although both genetics and environmental change played a role in animal diversification, the evolution of carnivory is thought to have set off an ecological arms race between predators and prey that fueled the observed Cambrian diversification of animals (Stanley 1973; Bengtson and Conway Morris 1992; Sperling et al. 2013) and algae (Knoll 1994; Vidal and Moczydłowska-Vidal 1997). Might the evolution of eukaryophagy have had a broadly comparable effect on Neoproterozoic ecosystems?

The ability to phagocytose bacteria and other small particles appears to be plesiomorphic among the Eukarya. Predation on large cells, however, is commonly derived and focused within a relatively small number of clades. Preliminary analysis of molecular clocks suggests that eukaryophagy evolved in several clades (including ciliates, dinoflagellates, amoebozoans, and rhizarians) during the Neoproterozoic Era, and the same logic that underpins ecological amplification of Cambrian animal diversifi- cation applies to this event. Indeed, Stanley's (1973) early formulation of the predation hypothesis can be applied at least as well to eukaryophagy in protists as it has been to carnivory in animals. Experiments indicate that protistan and micrometazoan grazers both result in increased growth rates and biomass for eukaryotic phytoplankton, but not cyanobacteria (Trommer et al. 2012; Ratti et al. 2013); thus, eukaryophagy could, in principle, have facilitated the rise of eukaryotic phytoplankton to ecological prominence.

Porter (2011) was the first to propose that protistan predation might have driven the observed Neoproterozoic expansion of eukaryotic fossils. Does this hypothesis make specific predictions that might be tested against the record? The vase-shaped tests introduced earlier provide three lines of evidence consistent with the eukaryophagy hypothesis. The first is phylogenetic; some of the testate microfossils in 750- to 800 -Mya rocks can be allied with a eukaryophagic amoebozoan clade (Porter et al. 2003). Then there is functional evidence; by their nature, these tests would have provided protection against eukaryophagic predators, so the midNeoproterozoic radiation of such structures is, again, consistent with the eukaryophagy hypothesis. Moreover, some preserved tests have regular half-moon perforations, thought to reflect attack by vampyrellid or other protistan predators (Porter et al. 2003).

Other evidence for protective armor comes from the $\sim 800$-Mya scale microfossils introduced earlier (Cohen and Knoll 2012). And then there is the expansion of multicellular and coenocytic fossils. Both theory and experiment suggest that multicellularity provides protection against protistan predators (e.g., Boraas et al. 1998). Intriguingly, as noted above, molecular clocks suggest that animals date from the mid-Neoproterozoic Era as well (Erwin et al. 2012), perhaps implicating eukaryophagy in the origin of animal multicellularity. At present, the idea that the establishment or expansion of eukaryophagy drove mid-Neoproterozoic eukaryotic diversification in the oceans remains a hypothesis to be tested by the careful integration of function and phylogeny, as well as con- 
A.H. Knoll

tinuing paleontological research. It does, however, have the merit of accounting for a broad spectrum of paleontological observations.

Last, we can ask about the environmental context of Neoproterozoic eukaryotic diversification. Increased microfossil diversity immediately preceded an interval of global glaciations, popularly known as the Snowball Earth (Hoffman et al. 1998). Changes in both export fluxes and mean Redfield ratios of an increasingly eukaryotic phytoplankton have been implicated in the $\mathrm{CO}_{2}$ drawdown that initiated glaciation (Tziperman et al. 2011), and decreasing $\mathrm{pCO}_{2}$ has, in turn, been postulated to drive adaptive evolution in Rubsico, the key enzyme in $\mathrm{CO}_{2}$ fixation by algae and cyanobacteria (Young et al. 2012). Tectonic changes also characterized the later Neoproterozoic Earth, and these also influenced atmospheric chemistry and climate. The key point for ongoing research is that an expanding ecological presence of eukaryotes in marine ecosystems may have provided important new feedback in the integrated Earth system, both facilitating and reflecting changes in the physical environment.

\section{CONCLUDING REMARKS}

Of course, eukaryotic diversification did not end with the close of the Proterozoic Eon. Indeed, most eukaryotic diversity is a product of Phanerozoic evolution. Fossils conspicuously record the radiations of complex multicellu- lar clades, first animals in the oceans and later embryophytic land plants, land animals, and morphologically complex fungi (e.g., Knoll 2011). The chemistry of sedimentary rocks indicates that the transition from Proterozoic to Phanerozoic ecosystems also involved environmental change. Animals radiated in Cambrian oceans richer in oxygen than their Proterozoic counterparts, with $\mathrm{pO}_{2}$ increasing to levels that matched or exceeded those of the present during the later Paleozoic Era (Berner 2009; Dahl et al. 2010). Protists diversified as well. Mineralized skeletons document the Paleozoic diversification of radiolarians and benthic foraminiferans followed by Mesozoic radiations of coccolithophorid algae, dinoflagellates, and diatoms, not to mention the expansion of foraminiferans into the planktonic realm (Lipps 1993).

Those radiations, however, are only the latest chapter in a much longer history of eukaryotic evolution. Careful field and laboratory investigations of Proterozoic sedimentary rocks are yielding increasing evidence of earlier eukaryotic diversification and its environmental context (Fig. 3). Uncertainties abound, but present evidence suggests that crown group eukaryotes radiated into a world quite distinct from today's, with moderately oxic surface oceans and, commonly, anoxia in subsurface water masses. As phylogenies, molecular clocks, paleoenvironmental reconstructions, and geochronological calibration all continue to im-

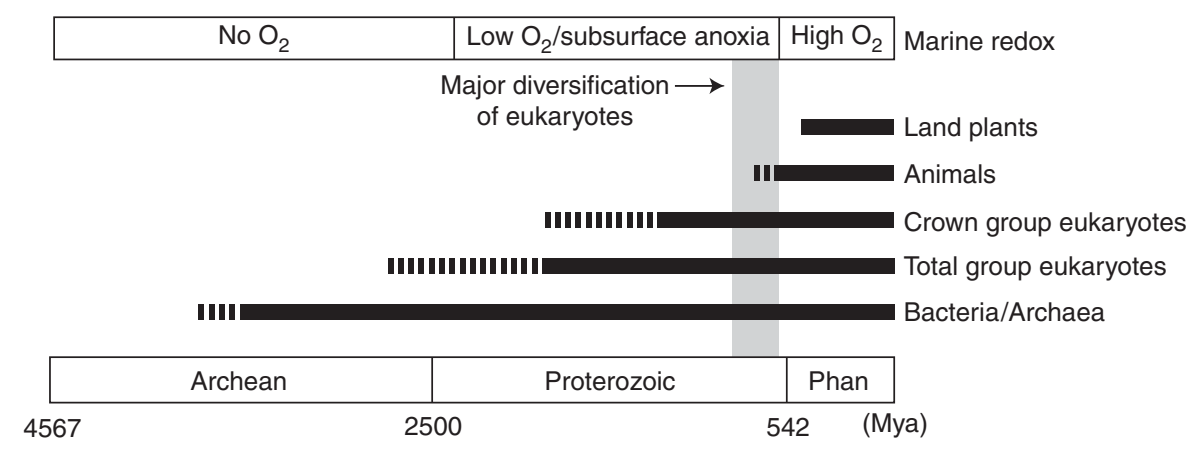

Figure 3. A summary of early eukaryotic evolution. Solid bars denote confident interpretation of geologic record; dashed bars indicate uncertain or controversial extensions of the record. Phan, Phanerozoic Eon (literally, the age of visible animal life). See text for references. 
prove, our interpretations of the early fossil record will become richer and better integrated with inferences from comparative biology.

\section{ACKNOWLEDGMENTS}

My thinking on eukaryotic evolution has benefitted from discussions with S. Porter, P. Cohen, M. Giordano, S. Ratti, P. Falkowski, L. Katz, L. Parfrey, and especially D. Lahr. I thank the NASA Astrobiology Institute for support, E. Javaux for comments on an earlier draft, and M. Walter, N. Butterfield, E. Javaux, S. Porter, and P. Cohen for images in Figures 1 and 2.

\section{REFERENCES}

${ }^{*}$ Reference is also in this collection

Adl SM, Simpson AGB, Lane CE, Lukeš J, Bass D, Bowser SS, Brown MW, Burki F, Dunthorn M, Hampl V, et al. 2012. The revised classification of eukaryotes. J Eukaryot Microbiol 59: 429-493.

Allard B, Templier J. 2000. Comparison of neutral lipid profile of various trilaminar outer cell wall (TLS)-containing microalgae with emphasis on algaenan occurrence. Phytochemistry 54: 369-380.

Allison CW, Hilgert JW. 1986. Scale microfossils from the early Cambrian of Northwest Canada. J Paleontol 60: 973-1015.

Anbar AD, Duan Y, Lyons TW, Arnold GL, Kendall B, Creaser RA, Kaufman AJ, Gordon GW, Scott C, Garvin J, et al. 2007. A whiff of oxygen before the great oxidation event? Science 317: 1903-1906.

Bauersachs T, Kremer B, Schoute S, Sinninghe Damsté JS. 2009. Biomarker and $\delta^{15} \mathrm{~N}$ study of thermally altered Silurian cyanobacterial mats. Org Geochem 40: 149-157.

Beers CD. 1948. Excystment in the ciliate Bursaria truncatella. Biol Bull 94: 86-98.

Beers CD. 1966. The excystment process in the ciliate Nassula ornata Ehrbg. J Protozool 13: 79-83.

Bengtson S, Conway Morris S. 1992. Early radiation of biomineralizing phyla. In Origin and early evolution of the metazoa (ed. Lipps J, Signor PW), pp. 447-481. Plenum, New York.

Berner RA. 2009. Phanerozoic atmospheric oxygen: New results using the GEOCARBSULF model. Am J Sci 309: 603-606.

Berney C, Pawlowski J. 2006. A molecular time-scale for eukaryote evolution recalibrated with the continuous microfossil record. Proc Biol Sci 273:1867-1872.

Boraas ME, Seale DB, Boxhorn JE. 1998. Phagotrophy by a flagellate selects for colonial prey: A possible origin of multicellularity. Evol Ecol 12: 153-164.

Boyle RA, Clark JR, Poulton SW, Shields-Zhou G, Canfield DE, Lenton TM. 2013. Nitrogen cycle feedbacks as a con- trol on euxinia in the mid-Proterozoic ocean. Nat Commun 4: 1533.

Brocks JJ. 2011. Millimeter-scale concentration gradients of hydrocarbons in Archean shales: Live-oil escape or fingerprint of contamination? Geochim Cosmochem Acta 75: 3196-3213.

Brocks JJ, Logan GA, Buick R, Summons RE. 1999. Archean molecular fossils and the early rise of eukaryotes. Science 285: $1033-1036$

Brocks JJ, Buick R, Summons RE, Logan GA. 2003. A reconstruction of Archean biological diversity based on molecular fossils from the 2.78 to 2.45 billion-year-old Mount Bruce Supergroup, Hamersley Basin, Western Australia. Geochim Cosmochim Acta 67: 4321-4335.

Brocks JJ, Love GD, Summons RE, Knoll AH, Logan GA, Bowden S. 2005. Biomarker evidence for green and purple sulfur bacteria in an intensely stratified Paleoproterozoic ocean. Nature 437: 866-870.

Butterfield NJ. 2000. Bangiomorpha pubescens n. gen., n. sp.: Implications for the evolution of sex, multicellularity, and the Mesoproterozoic/Neoproterozoic radiation of eukaryotes. Paleobiology 26: 386-404.

Butterfield NJ. 2004. A vaucherian alga from the Middle Neoproterozoic of Spitsbergen: Implications for the evolution of Proterozoic eukaryotes and the Cambrian explosion. Paleobiology 30: 231-252.

Butterfield NJ. 2005a. Probable Proterozoic fungi. Paleobiology 31: 165-182.

Butterfield NJ. 2005b. Reconstructing a complex Early Neoproterozoic eukaryote, Wynniatt Formation, Arctic Canada. Lethaia 38: 155-169.

Butterfield NJ, Knoll AH, Swett K. 1994. Paleobiology of the Upper Proterozoic Svanbergfjellet Formation, Spitsbergen. Fossils Strata 34: 1-84.

Canfield DE. 2005. The early history of atmospheric oxygen: Homage to Robert M. Garrels. Annu Rev Earth Planet Sci 33: $1-36$.

Chakrabarti R, Knoll AH, Jacobsen SB, Fischer WW. 2012. Silicon isotopic variability of Proterozoic cherts. Geochim Cosmochim Acta 91: 187-201.

Chernikova D, Motamedi S, Csueroes M, Koonin EV, Rogozin IB. 2011. A late origin of the extant eukaryotic diversity: Divergence time estimates using rare genomic changes. Biol Direct 6: 26.

Cohen PA, Knoll AH. 2012. Neoproterozoic scale microfossils from the Fifteenmile Group, Yukon Territory. J Paleontol 86: 775-800.

Cohen PA, Schopf JW, Butterfield NJ, Kudryavtsev AB, Macdonald FA. 2011. Phosphate biomineralization in midNeoproterozoic protists. Geology 39: 539-542.

Dahl TW, Hammarlund E, Gill BC, Knoll AH, Anbar AD, Gordon GW, Bond DPG, Schovsbo NH, Nielsen AT, Canfield DE. 2010. Devonian rise in atmospheric oxygen correlated to the radiations of terrestrial plants and large predatory fish. Proc Natl Acad Sci 107: 17853-18232.

Douzery EJP, Snell EA, Bapteste E, Delsuc F, Philippe H. 2004. The timing of eukaryotic evolution: Does a relaxed molecular clock reconcile proteins and fossils? Proc Natl Acad Sci 108: 15386-15391.

Dutkiewicz A, Volk H, George SC, Ridley J, Buick R. 2006. Biomarkers from Huronian oil-bearing fluid inclusions: 
A.H. Knoll

An uncontaminated record of life before the great oxidation event. Geology 34: 437-440.

* Eme L, Sharpe SC, Brown MW, Roger AJ. 2014. On the age of eukaryotes: Evaluating evidence from fossils and molecular clocks. Cold Spring Harb Perspect Biol doi: 10.1101/ cshperspect.a016139.

Erwin DH, Laflamme M, Tweedt S, Sperling EA, Pisani D, Peterson KJ. 2011. The Cambrian conundrum: Early divergence and later ecological success in the early history of animals. Science 334: 1091-1097.

Fennel K, Follows M, Falkowski PG. 2005. The coevolution of the nitrogen, carbon and oxygen cycles in the Proterozoic ocean. Am J Sci 305: 526-545.

Fischer WW, Knoll AH. 2009. An iron-shuttle for deep water silica in Late Archean and Early Paleoproterozoic iron formation. Geol Soc Am Bull 121: 222-235.

Foissner W, Mueller H, Agatha S. 2007. A comparative fine structural and phylogenetic analysis of resting cysts in oligotrich and hypotrich Spirotrichea (Ciliophora). Eur J Protistol 43: 295-314.

Frei R, Gaucher C, Stolper D, Canfield DE. 2013. Fluctuations in late Neoproterozoic atmospheric oxidation- $\mathrm{Cr}$ isotope chemostratigraphy and iron speciation of the late Ediacaran lower Arroyo del Soldado Group (Uruguay). Gondwana Res 23: 797-811.

Gingras M, Hagadorn JW, Seilacher A, Lalonde SV, Pecoit E, Petrash D, Konhauser KO. 2011. Possible evolution of mobile animals in association with microbial mats. Nat Geocience 4: 372-375.

Graham LE, Cook ME, Wilcox LW, Graham J, Taylor W, Wellman CH, Lewis L. 2013. Resistance of filamentous chlorophycean, ulvophycean, and xanthophycean algae to acetolysis: Testing Proterozoic and Paleozoic microfossil attributions. Int J Plant Sci 174: 947-957.

Grey K, Williams IR. 1990. Problematic bedding-plane markings from the Middle Proterozoic Manganese Subgroup, Bangemall Basin, Western Australia. Precambrian Res 46: 307-327.

Grice K, Cao CQ, Love GD, Böttcher ME, Twitchett RJ, Grosjean E, Summons RE, Turgeon SC, Dunning W, Jin Y. 2005. Photic zone euxinia during the Permian-Triassic superanoxic event. Science 307: 706-709.

Gupta NS, Cody GD, Tetlie OE, Briggs DEG, Summons RE. 2009. Rapid incorporation of lipids into macromolecules during experimental decay of invertebrates: Initiation of geopolymer formation. Org Geochem 40: 589-594.

Han TM, Runnegar B. 1992. Megascopic eukaryotic algae from the 2.1-billion-year-old Negaunee Iron-Formation, Michigan. Science 257: 232-235.

Hayes JM. 1994. Global methanotrophy at the ArcheanProterozoic transition. In Early life on earth (ed. Bengtson S), pp. 220-236. Columbia University Press, New York.

Hedges SB, Blair JE, Venturi ML, Shoe JL. 2004. A molecular timescale of eukaryote evolution and the rise of complex multicellular life. BMC Evol Biol 4: 2.

Hoffman PF, Kaufman AJ, Halverson GP, Schrag DP. 1998. A Neoproterozoic Snowball Earth. Science 281: $1342-$ 1346.
Hofmann HJ, Chen J. 1981. Carbonaceous megafossils from the Precambrian (1800 Ma) near Jixian, northern China. Can J Earth Sci 18: 443-447.

Holland HD. 2006. The oxygenation of the atmosphere and oceans. Phil Trans R Soc Lond B Biol Sci 361: 903-915.

Javaux E. 2011. Early eukaryotes in Precambrian oceans. In Origins and evolution of life: An astrobiological perspective (ed. Gargaud M, et al.), pp. 414-449. Cambridge University Press, Cambridge, UK.

Javaux E, Knoll AH, Walter MR. 2001. Ecological and morphological complexity in early eukaryotic ecosystems. Nature 412: 66-69.

Javaux E, Knoll AH, Walter MR. 2003. Recognizing and interpreting the fossils of early eukaryotes. Orig Life Evol Biosph 33: 75-94.

Javaux E, Knoll AH, Walter MR. 2004. TEM evidence for eukaryotic diversity in mid-Proterozoic oceans. Geobiology 2: 121-132.

Javaux EJ, Marshall CP, Bekker A. 2010. Organic-walled microfossils in 3.2-billion-year-old shallow-marine siliciclastic deposits. Nature 463: 934-938.

Johnston DT, Wolfe-Simon F, Pearson A, Knoll AH. 2009. Anoxygenic photosynthesis modulated Proterozoic oxygen and sustained Earth's middle age. Proc Natl Acad Sci 106: $16925-16929$.

Johnston DT, Poulton SW, Dehler C, Porter S, Husson J, Canfield DE, Knoll AH. 2010. An emerging picture of Neoproterozoic ocean chemistry: Insight from the Chuar Group, Grand Canyon, USA. Earth Planet Sci Lett 290: 64-73.

Katz LA. 2012. Origin and diversification of eukaryotes. Annu Rev Microbiol 66: 411-427.

Knoll AH. 1994. Proterozoic and Early Cambrian protists: Evidence for accelerating evolutionary tempo. Proc Natl Acad Sci 91: 6743-6750.

Knoll AH. 2011. The multiple origins of complex multicellularity. Annu Rev Earth Planet Sci 39: 217-239.

Knoll AH, Kotrc B. 2014. Protistan skeletons: A geologic history of evolution and constraint. In Evolution of lightweight structures (ed. Hamm C). Springer-Verlag, Berlin (to be published).

Knoll AH, Swett K. 1990. Carbonate deposition during the late Proterozoic era: An example from Spitsbergen. Am J Sci 290-A: 104-132.

Knoll AH, Javaux EJ, Hewitt D, Cohen P. 2006. Eukaryotic organisms in Proterozoic oceans. Philos Trans R Soc Lond B Biol Sci 361: 1023-1038.

Knoll AH, Summons RE, Waldbauer J, Zumberge J. 2007. The geological succession of primary producers in the oceans. In The evolution of primary producers in the sea (ed. Falkowski P, Knoll AH), pp. 133-163. Elsevier, Burlington, MA.

Knoll AH, Wörndle S, Kah L. 2013. Covariance of microfossil assemblages and microbialite textures across a late Mesoproterozoic carbonate platform. Palaios 28: 453470.

Kodner RB, Summons RE, Pearson A, Knoll AH. 2008. Sterols in red and green algae: Quantification, phylogeny and relevance for the interpretation of geologic steranes. Geobiology 6: 411-420. 
Kodner R, Knoll AH, Summons RE. 2009. Phylogenetic investigation of the aliphatic, non-hydrolyzable biopolymer algaenan, with a focus on the green algae. Org Geochem 40: 854-862.

Lamb DM, Awramik SM, Chapman DJ, Zhu S. 2009. Evidence for eukaryotic diversification in the $\sim 1800$ million-year-old Changzhougou Formation, North China. Precambrian Res 173: 93-104.

Lipps JH, ed. 1993. Fossil prokaryotes and protists. Blackwell, Cambridge, MA.

Martin W, Müller M. 1998. The hydrogen hypothesis for the first eukaryote. Nature 392: 37-41.

Moczydłowska M. 2010. Life cycle of early Cambrian microalgae from the Skiagia-plexus acritarchs. J Paleontol 84: $216-230$.

Moczydłowska M, Landing E, Zang W, Palacios T. 2011. Proterozoic phytoplankton and timing of Chlorophyte algae orgins. Palaeontology 54: 721-733.

Moreira D, Lopez Garcia P. 1998. Symbiosis between methanogenic archaea and $\delta$-proteobacteria as the origin of eukaryotes: The syntrophic hypothesis. J Mol Evol 47: 517-530.

Müller M, Mentel M, van Hellemond JJ, Henze K, Woehle K, Gould SB, Yu R-Y, van der Giezen M, Tielens AG, Martin WF, et al. 2012. Biochemistry and evolution of anaerobic energy metabolism in eukaryotes. Microbiol Mol Biol Revs 76: $444-495$.

Nagovitsin KE, Stanevich AM, Kornilova TA. 2010. Stratigraphic setting and age of the complex Tappania-bearing Proterozoic fossil biota of Siberia. Russ Geol Geophys 51: $1192-1198$.

Pang K, Tang Q, Schiffbauer D, Yao J Yuan X, Wan B, Chen L, Xiao S. 2013. The nature and origin of nucleus-like intracellular inclusions in Paleoproterozoic eukaryote microfossils. Geobiology 13: 499-510.

Parfrey L, Lahr D, Knoll AH, Katz LA. 2011. Estimating the timing of early eukaryotic diversification with multigene molecular clocks. Proc Natl Acad Sci 108: 13624-13629.

Patterson DJ. 1999. The diversity of eukaryotes. Am Nat 154: S96-S124.

Pawlowska MM, Butterfield NJ, Brocks JJ. 2013. Lipid taphonomy in the Proterozoic and the effect of microbial mats on biomarker preservation. Geology 41: 103106.

Pearson A, Budin M, Brocks JJ. 2005. Phylogenetic biochemical evidence for sterol synthesis in the bacterium Gemmata obsuriglobus. Proc Natl Acad Sci 100: $15352-$ 15357.

Porter SM. 2011. The rise of predators. Geology 39: 607608.

Porter SM, Knoll AH. 2000. Testate amoebae in the Neoproterozoic Era: Evidence from vase-shaped microfossils in the Chuar Group, Grand Canyon. Paleobiology 26: 360-385.

Porter SM, Meisterfeld R, Knoll AH. 2003. Vase-shaped microfossils from the Neoproterozoic Chuar Group, Grand Canyon: A classification guided by modern testate amoebae. J Paleontol 77: 205-225.

Rasmussen B, Fletcher IR, Brocks JJ, Kilburn MR. 2008. Reassessing the first appearance of eukaryotes and cyanobacteria. Nature 455: 1101-1104.
Ratti S, Knoll AH, Giordano M. 2013. Grazers and phytoplankton growth in the oceans: An experimental and evolutionary perspective. PLoS ONE 8: e77349.

Retallack GJ, Dunn KL, Saxby J. 2013. Problematic Mesoproterozoic fossil Horodyskia from Glacier National Park, Montana, USA. Precambrian Res 226: 125-142.

Roger AJ, Hug LA. 2006. The origin and diversification of eukaryotes: Problems with molecular phylogenetics and molecular clock estimation. Philos Trans R Soc Lond B Biol Sci 361:1039-1054.

Schultz HN, Jørgensen BB. 2001. Big bacteria. Annu Rev Microbiol 55: 105-137.

Schwark L, Empt P. 2006. Sterane biomarkers as indicators of Palaeozoic algal evolution and extinction events. $\mathrm{Pa}$ laeogeogr Palaeoclimatol Palaeoecol 240: 225-236.

Scott C, Lyons TW, Bekker A, Shen Y, Poulton SW, Chu X, Anbar AD. 2008. Tracing the stepwise oxygenation of the Proterozoic ocean. Nature 452: 456-459.

Shih PM, Matzke MJ. 2013. Primary endosymbiosis events date to the later Proterozoic with cross-calibrated phylogenetic dating of duplicated ATPase proteins. Proc Natl Acad Sci 110: $12355-12360$.

Sperling EA, Frieder CA, Raman AV, Girguis PR, Levin LA, Knoll AH. 2013. Oxygen, ecology, and the Cambrian radiation of animals. Proc Natl Acad Sci 110: $13446-$ 13451.

Stanley SM. 1973. An ecological theory for the sudden origin of multicellular life in the late Precambrian. Proc Natl Acad Sci 70: 1486-1489.

Strother PK, Battison L, Brasier MD, Wellman CH. 2010. Earth's earliest non-marine eukaryotes. Nature 473: 505 509.

Talyzina N, Moczydłowska M. 2000. Morphological and ultrastructural studies of some acritarchs from the Lower Cambrian Lukati Formation, Estonia. Rev Palaeobot Palynol 112: 1-21.

Trommer G, Pondaven P, Siccha M, Stibor H. 2012. Zooplankton-mediated nutrient limitation patterns in marine phytoplankton: An experimental approach with natural communities. Mar Ecol Prog Ser 449: 83-94.

Tziperman E, Halevy I, Johnston D, Knoll AH, Schrag D. 2011. Biologically induced initiation of Snowball-Earth events. Proc Natl Acad Sci 108: 15091-15096.

Verni F, Rosati G. 2011. Resting cysts: A surivival strategy in Protozoa Ciliophora. Ital J Zool 78: 134-145.

Vidal G, Moczydłowska-Vidal M. 1997. Biodiversity, speciation, and extinction trends of Proterozoic and Cambrian phytoplankton. Paleobiology 23: 230-246.

Waldbauer JR, Sherman LS, Sumner DY, Summons RE. 2009. Late Archean molecular fossils from the Transvaal Supergroup record the antiquity of microbial diversity and aerobiosis. Precambrian Res 169: 28-47.

Waldbauer JR, Newman DK, Summons RE. 2011. Microaerobic steroid biosynthesis and the molecular fossil record of Archean life. Proc Natl Acad Sci 108: $13408-$ 13414.

Walter MR, Du R, Horodyski RJ. 1990. Coiled carbonaceous megafossils from the Middle Proterozoic of Jixian (Tianjin) and Montana. Am J Sci 290A: 133-148.

Wang DYC, Kumar S, Hedges SB. 1999. Divergence time estimates for the early history of animal phyla and the 
A.H. Knoll

origin of plants, animals and fungi. Philos Trans $R$ Soc Lond B Biol Sci 266: 163-171.

Williams TA, Foster PG, Nye TMW, Cox CJ, Embley TM. 2012. A congruent phylogenomic signal places eukaryotes within the Archaea. Philos Trans R Soc Lond B Biol Sci 279: $4870-4879$.

Woese CR, Kandler O, Wheelis ML. 1990. Towards a natural system of organisms: Proposal for the domains Archaea, Bacteria, and Eukarya. Proc Natl Acad Sci 87: 4576-4579.

Xiao S, Knoll AH, Zhang Y, Yin L. 1997. Neoproterozoic fossils in Mesoproterozoic rocks? Chemostratigraphic resolution of a biostratigraphic conundrum from the North China Platform. Precambrian Res 84: $197-220$.
Yan YZ. 1995. Shale facies microfloras from lower Changcheng System in Kuancheng, Hebei, and comparison with those of neighboring areas. Acta Micropalaeontol Sinica 12: 349-373.

Yin L, Yuan X. 2007. Radiation of Meso-Neoproterozoic and early Cambrian protists inferred from the microfossil record of China. Palaeogeogr Palaeoclimatol Palaeoecol 254: 350-361.

Yoon HS, Hackett JD, Ciniglia C, Pinto G, Bhattacharya D. 2004. A molecular timeline for the origin of photosynthetic eukaryotes. Mol Biol Evol 21: 809-818.

Young JN, Rickaby REM, Kapralov MV, Filatov DA. 2012. Adaptive signals in algal Rubisco reveal a history of ancient atmospheric carbon dioxide. Philos Trans $R$ Soc Lond B Biol Sci 367: 483-492. 


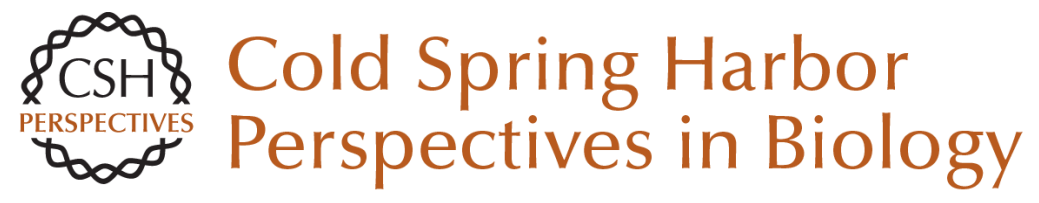

\section{Paleobiological Perspectives on Early Eukaryotic Evolution}

Andrew H. Knoll

Cold Spring Harb Perspect Biol 2014; doi: 10.1101/cshperspect.a016121

Subject Collection The Origin and Evolution of Eukaryotes

The Persistent Contributions of RNA to Eukaryotic Gen(om)e Architecture and Cellular Function Jürgen Brosius

Green Algae and the Origins of Multicellularity in the Plant Kingdom James G. Umen

The Archaeal Legacy of Eukaryotes: A

Phylogenomic Perspective

Lionel Guy, Jimmy H. Saw and Thijs J.G. Ettema

Origin and Evolution of the Self-Organizing Cytoskeleton in the Network of Eukaryotic Organelles Gáspár Jékely

On the Age of Eukaryotes: Evaluating Evidence from Fossils and Molecular Clocks Laura Eme, Susan C. Sharpe, Matthew W. Brown, et al.

Origin of Spliceosomal Introns and Alternative Splicing Manuel Irimia and Scott William Roy

Protein and DNA Modifications: Evolutionary Imprints of Bacterial Biochemical Diversification and Geochemistry on the Provenance of Eukaryotic Epigenetics

L. Aravind, A. Maxwell Burroughs, Dapeng Zhang, et al.
Eukaryotic Origins: How and When Was the Mitochondrion Acquired?

Anthony M. Poole and Simonetta Gribaldo

Bacterial Influences on Animal Origins Rosanna A. Alegado and Nicole King

Missing Pieces of an Ancient Puzzle: Evolution of the Eukaryotic Membrane-Trafficking System Alexander Schlacht, Emily K. Herman, Mary J. Klute, et al.

The Neomuran Revolution and Phagotrophic Origin of Eukaryotes and Cilia in the Light of Intracellular Coevolution and a Revised Tree of Life

Thomas Cavalier-Smith

Protein Targeting and Transport as a Necessary

Consequence of Increased Cellular Complexity Maik S. Sommer and Enrico Schleiff

How Natural a Kind Is "Eukaryote?" W. Ford Doolittle

What Was the Real Contribution of Endosymbionts to the Eukaryotic Nucleus? Insights from Photosynthetic Eukaryotes David Moreira and Philippe Deschamps

For additional articles in this collection, see http://cshperspectives.cshlp.org/cgi/collection/

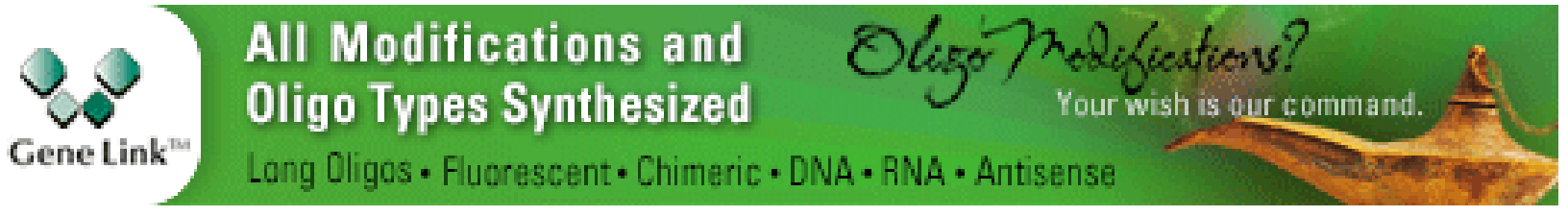


The Eukaryotic Tree of Life from a Global Phylogenomic Perspective Fabien Burki
Bioenergetic Constraints on the Evolution of Complex Life

Nick Lane

For additional articles in this collection, see http://cshperspectives.cshlp.org/cgi/collection/

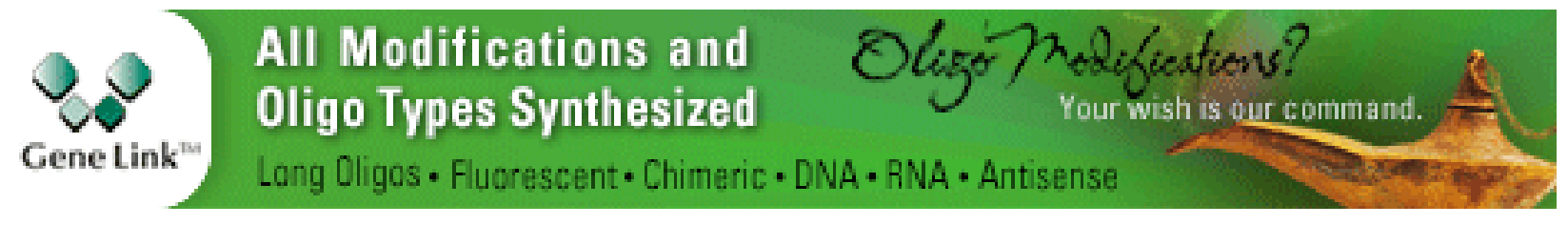

Copyright @ 2014 Cold Spring Harbor Laboratory Press; all rights reserved 